\title{
Benign Pigmented
}

\section{Schwannoma of the Great}

\section{Omentum: Report of a Rare}

Case and Review of the

Literature

\author{
Yusuke Tanoue Nobutaka Tanaka Motoki Nagai \\ Yoshio Suzuki
}

Department of General Surgery, Asahi General Hospital, Asahi, Japan

\section{Key Words}

Schwannoma Omentum $\cdot$ Neurofibroma $\cdot$ Cholelithiasis

\begin{abstract}
Schwannoma in the abdomen is an uncommon neoplasm that occurs most frequently in the cranial and peripheral nerves; it is extremely rare in the great omentum and only 6 cases of schwannoma of the great omentum have been observed previously. We report the case of a schwannoma found in the great omentum of a 55-year-old man who was treated with laparoscopic surgery. Though it was difficult to diagnose preoperatively, the tumor showed malignant potential by rapidly increasing in size. Histologically it was configured by a well-encapsulated round mass measuring $30 \times 18 \times 15 \mathrm{~mm}$ in diameter. Immunohistochemically most of the neoplastic cells reacted moderately to NSE, NCAM and S-100 protein. We document the clinicopathological study of a schwannoma of the great omentum, followed by a review of the literature.
\end{abstract}

\section{Introduction}

Schwannomas are neoplasms of the nerve sheath arising from Schwann cells. They are found most commonly in the cranial and peripheral nerves, and occurrence in the omentum is very rare. However, there have been some cases reported to develop serious complications and, if there was malignancy, to cause metastasis or recurrence. We presented a case of schwannoma originating from the great omentum, including histological and immunohistological studies. 


\section{Case Report}

A 55-year-old man was referred to our department for the treatment of a tumor detected close to the stomach by ultrasound. Medical examination including ultrasound had been regularly performed to follow up his gallbladder stone for the past 6 years. Although he had no complaints and symptoms, the tumor had been increasing in size over one year. Abdominal and endoscopic ultrasound showed a $2.0 \times 1.3 \mathrm{~cm}$ cystic mass lateral to the wall of the stomach. Its component included an $11.8 \times 5.7 \mathrm{~mm}$ elevated lesion (fig. 1, fig. 2). Computed tomography scan of the abdomen and pelvis showed a $2.6 \times 1.9 \mathrm{~cm}$ cystic mass, which was slightly enhanced, and a gallbladder stone ( $\underline{\mathrm{fig}}$. 3 ). Magnetic resonance imaging demonstrated a hyperintense mass on T2-weighted image. A distance from the stomach wall was detected (fig. 4 ). His medical history documented nothing particular. Physical examination revealed no abnormalities. Laboratory tests, including tumor makers, were normal.

Under a perioperative diagnosis of cystic tumor in the abdomen and cholelithiasis, we performed laparoscopic resection with vessel sealing system, which revealed a $2.0 \mathrm{~cm}$ mass arising from the great omentum, not adherent to other organs. Grossly, the tumor was configured by a well-encapsulated round mass measuring $30 \times 18 \times 15 \mathrm{~mm}$ in diameter (fig. 5). The resected tissue was fixed and stained with hematoxylin and eosin. Histologically, the spindle-shaped cells were arranged in interlacing bundles and fascicles, together with varying numbers of tumor cells containing various amounts of light brown or grayish pigment (fig. 6). The Antoni A regions consist of compact areas of spindle cells with pink cytoplasm. These alternate with looser Antoni B tissue, which is comprised of cells showing clear, vacuolated cytoplasm due to lipid accumulation. Immunohistochemically, most of the neoplastic cells reacted moderately to NSE, NCAM and S-100 protein (fig. 7).

Based on the histological and immunohistochemical features, the present case was diagnosed as peripheral pigmented schwannoma. The postoperative course was uneventful and he was well 4 months after surgery.

\section{Discussion}

Schwannomas are classified as one kind of the peripheral nerve sheath tumors, of which schwannnoma and neurofibroma are the most frequent. Currently, the most precise determination of the tumor's cell type is established by its immunohistochemical profile, ultrastructural features, or both. A tumor composed of cells with distinctly Schwannian characteristics is designated schwannoma. Schwannomas are known to mainly arise from the peripheral and caranial nerves, the extremities and the retroperitoneum. They are seldom found in the abdomen, especially the extragastrointestinal tract, of which solitaly schwannoma of the great omentum is an extremely rare tumor. In 303 schwannomas reported by Das Gupta et al. [1], one case originated from the retroperitoneum, others from the central nervous system and peripheral nerve. In another review of the literature, Stout and Carson [2] found 246 cases of schwannoma. Of these, 37 were in the stomach, 3 in the small bowel, and none in the omentum and the abdominal cavity. Previously published cases of schwannoma in the omentum were collected from a computerized medical literature search (PubMed). Only 6 cases of schwannoma from the great omentum have been observed [3-6] (table 1). We can see that more cases of schwannoma from the lesser omentum have been recorded than from the great omentum. It is mentioned that the lesser omentum contains a small amount of nerves in almost equal distribution, the great omentum has a paucity of nervous tissue and anatomically consists of fat and lymphatic tissue [3].

Schwannomas are a subclass of soft tissue neoplasms that include benign and malignant types. Malignant schwannomas are characterized by metastasis and severe prognosis. We found a case of malignant schwannoma arising from the omentum which demonstrated peritoneal metastasis [5], and another reported case of the small intestine emphasized poor prognosis since only 2 of 24 patients survived for more than 5 years [7]. Benign schwannomas are also reported to increase in size and to eventually cause 
complications by compressing other organs or by causing bleeding in or outside the gastrointestinal tract [3]. Pigmented schwannoma is another type of schwannoma, usually arising from the sympathetic nervous system. One report suggested it might be related to the malignant potential to metastasize [9].

Additionally abdominal schwannomas cause diagnostic problems because clinical symptoms are uncharacteristic or misleading even if the tumor is large. Some imaging examinations have been introduced to diagnose preoperatively [10]. CT imaging typically showed a low attenuation mass, peripheral enhancement and cystic degeneration pattern [8]. MRI disclosed schwannoma of low signal intensity on T1-weighted image and high signal intensity on $\mathrm{T} 2$-weighted image.

In spite of these characteristic, it is difficult to exclude other abdominal tumors, leiomyomas, lymphomas and unspecified sarcomas etc. While previous cases confirm that the tumor may attain a considerable size, bigger than $5 \mathrm{~cm}$ or producing symptoms, our case of a schwannoma which was small and asymptomatic is hardly diagnosed. However this tumor showing progression in size is thought to have potential to behave very aggressively despite benign histological features, which stresses the need of more information on this type of tumor and diagnosis.

Consequently, histological analysis of the surgical specimen is necessary for a correct diagnosis, and common treatment for schwannoma is surgery. Therefore laparoscopic resection seemed to be the most adequate method to diagnose and rule out malignant tumor as a minimally invasive surgery. The majority of tumors can be safely resected, the surgeon being careful of the dividing feeder vessels because schwannomas are well known as hypervascular tumors. To our knowledge there are no case reports documenting other treatments, including chemotherapy for schwannomas in the abdominal cavity.

Table 1. Previous case reports of schwannoma of the great omentum

\begin{tabular}{|c|c|c|c|c|c|}
\hline Age & Sex & Symptom & Complication & Size & Author \\
\hline 64 & male & vertigo & $\begin{array}{l}\text { intraperitoneal } \\
\text { bleeding }\end{array}$ & $9 \mathrm{~cm}$ & Bankier (1996) [3] \\
\hline 23 & female & $\begin{array}{l}\text { swelling of the } \\
\text { abdomen }\end{array}$ & $\mathrm{ND}$ & $3.5 \mathrm{~cm}(?)$ & Jhala (1972) [6] \\
\hline 60 & male & ND & ND & the head of a small child & Nowicki (1966) [11] \\
\hline 42 & male & abdominal pain & losing weight & $30 \times 15 \mathrm{~cm}$ & Matsuda (1984) [5] \\
\hline 56 & male & $\begin{array}{l}\text { swelling of the } \\
\text { abdomen }\end{array}$ & ND & $15.5 \times 14 \mathrm{~cm}$ & Kanataka (1974) [5] \\
\hline 58 & male & abdominal pain & $\begin{array}{l}\text { intraperitoneal } \\
\text { bleeding }\end{array}$ & $13 \times 13 \times 10 \mathrm{~cm}$ & Martorell (1989) [4] \\
\hline 55 & male & asymptomatic & none & $30 \times 18 \times 15 \mathrm{~mm}$ & our case \\
\hline
\end{tabular}




\begin{tabular}{r|l|l|l} 
Case Reports in & $\begin{array}{l}\text { Case Rep Gastroenterol 2009;3:222-229 } \\
\text { D0I: 10.1159/000228896 }\end{array}$ & Published online: August 28, 2009 & $\begin{array}{l}\text { O 2009 S. Karger AG, Basel } \\
\text { ISSN 1662-0631 } \\
\text { www.karger.com/crg }\end{array}$ \\
\hline
\end{tabular}

Fig. 1. Gastric fiber examination disclosed elevated wall of the stomach pressed by the tumor.

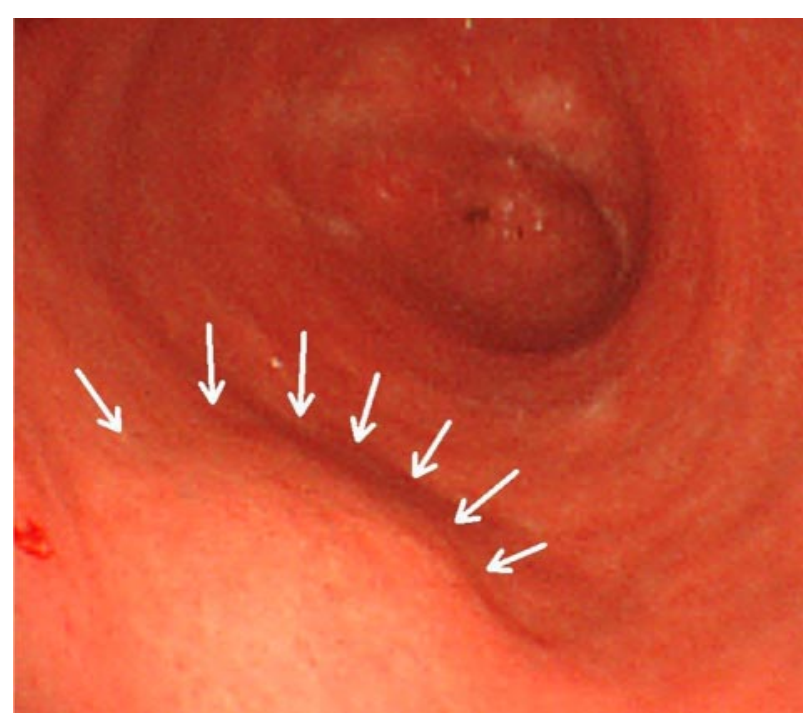

Fig. 2. Endoscopic ultrasound showed the cystic lesion including a $11.8 \times 5.7 \mathrm{~mm}$ elevated lesion and a $5.4 \times 2.4 \mathrm{~mm}$ one.

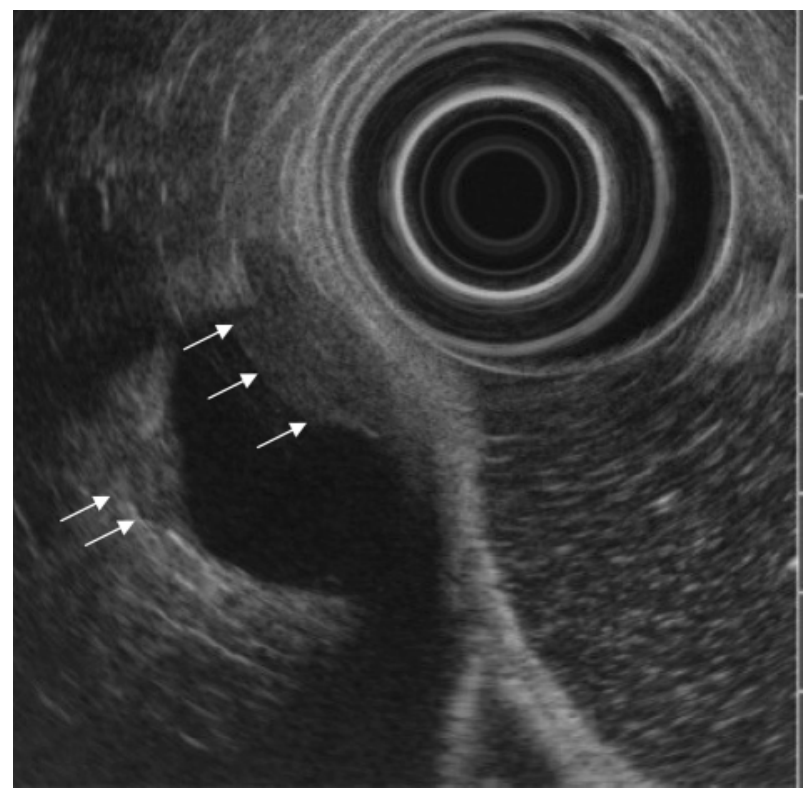




\begin{tabular}{r|l|l|l} 
Case Reports in & $\begin{array}{l}\text { Case Rep Gastroenterol 2009;3:222-229 } \\
\text { D0I: 10.1159/000228896 }\end{array}$ & Published online: August 28, 2009 & $\begin{array}{l}\text { O 2009 S. Karger AG, Basel } \\
\text { ISSN 1662-0631 } \\
\text { www.karger.com/crg }\end{array}$ \\
\hline
\end{tabular}

Fig. 3. Enhanced CT demonstrated an ovoid mass lateral to the stomach (arrows). The mass lesion contained central cystic component. The right gastropiploic artery passed posterior to the mass lesion.

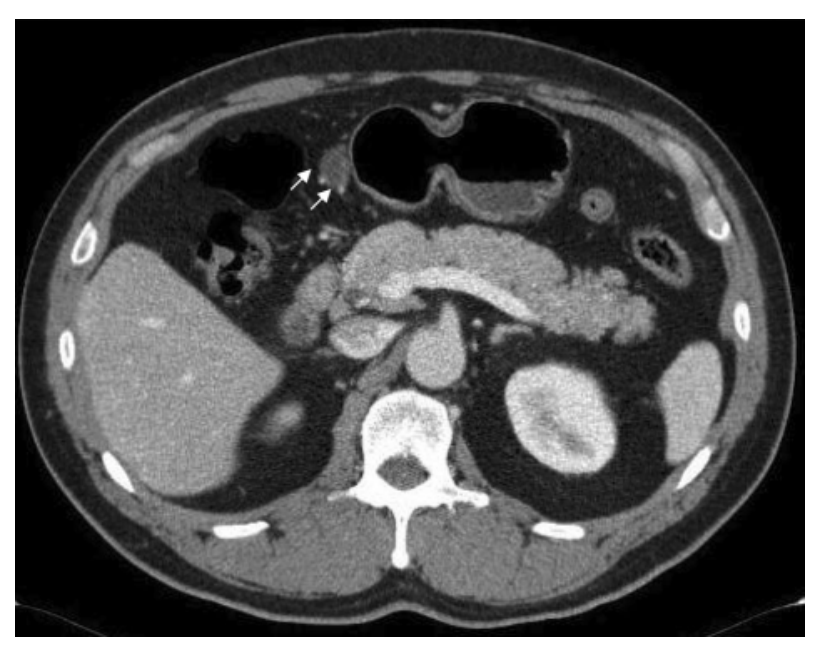

Fig. 4. MRI showed a highly enhancing mass with the surrounding vessels of the great omentum on T2-weighted image. The tumor was well-circumscribed.

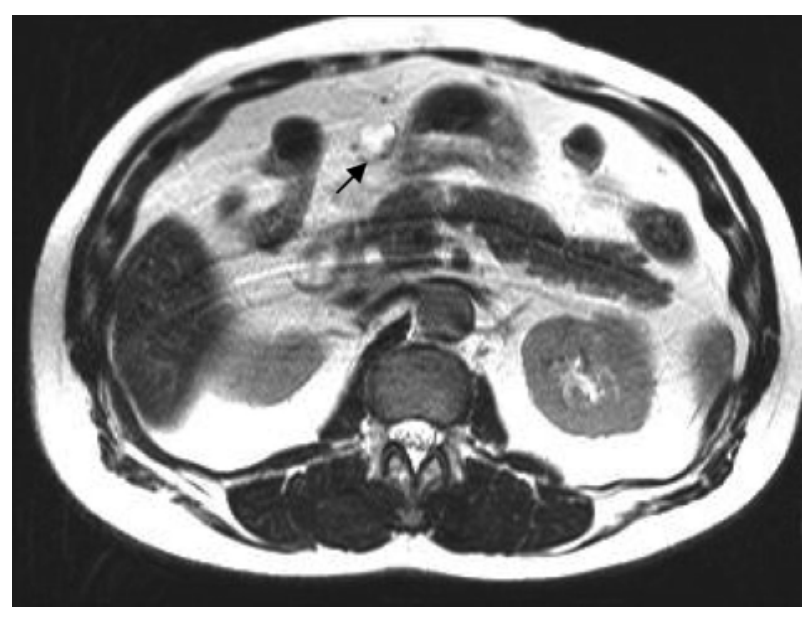




\begin{tabular}{r|l|l|l} 
Case Reports $/ \mathrm{h}$ & $\begin{array}{l}\text { Case Rep Gastroenterol 2009;3:222-229 } \\
\text { D0I: 10.1159/000228896 }\end{array}$ & Published online: August 28, 2009 & $\begin{array}{l}\text { O 2009 S. Karger AG, Basel } \\
\text { ISSN 1662-0631 } \\
\text { www.karger.com/crg }\end{array}$ \\
\hline
\end{tabular}

Fig. 5. Macroscopical feature of the tumor. The mass was $30 \times 18 \times 15 \mathrm{~mm}$ in diameter, revealing a smooth surface.

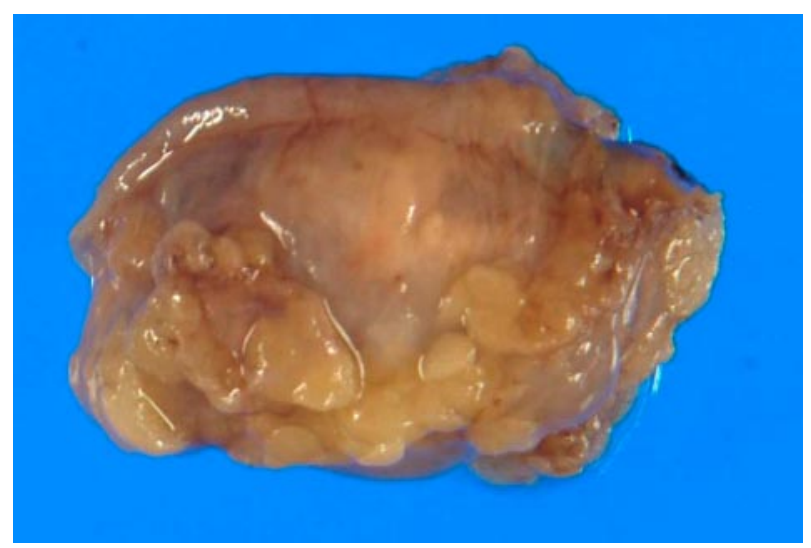

Fig. 6. Microscopical feature of the tumor. Hematoxylin and eosin staining. It was composed of spindle-shaped cells.

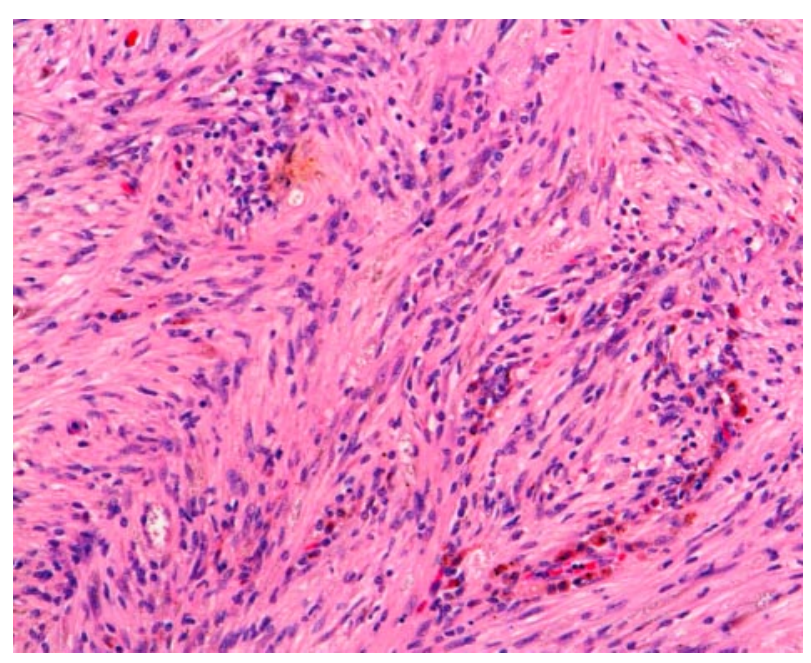




\begin{tabular}{r|l|l|l} 
Case Reports $/ \mathrm{h}$ & $\begin{array}{l}\text { Case Rep Gastroenterol 2009;3:222-229 } \\
\text { D0I: 10.1159/000228896 }\end{array}$ & Published online: August 28, 2009 & $\begin{array}{l}\text { O 2009 S. Karger AG, Basel } \\
\text { ISSN 1662-0631 } \\
\text { www.karger.com/crg }\end{array}$ \\
\hline
\end{tabular}

Fig. 7. Immunohistochemically, most of the tumor cells reacted to S-100.

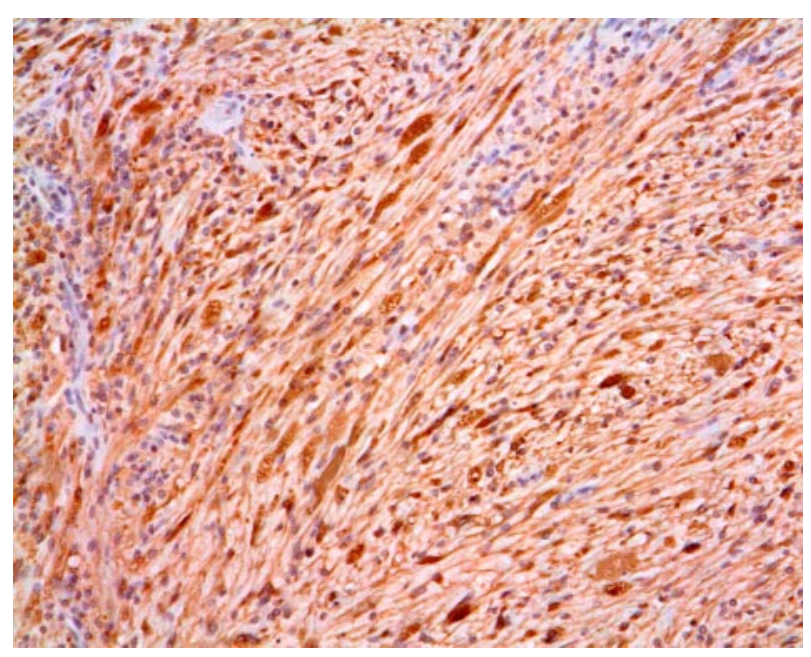




\section{References}

1 Das Gupta TK, Brasfield RD, Strong EW, Hajdu SI: Benign solitary Schwannomas (neurilemomas). Cancer 1969;24:355-366.

2 Stout $\mathrm{P}$, Carson W: The peripheral manifestation of the specific nerve sheath tumor. Am J Cancer 1935;24:751-796.

3 Bankier AA, Stanek C, Hübsch P: Case report: benign solitary schwannoma of the greater omentum: a rare cause of acute intraperitoneal bleeding - diagnosis by CT. Clin Radiol 1996;51:517-518.

-4 Martorell MA, Calabuig MC, Llombart-Bosch A, Esquerdo J: Primary omental tumor with ultrastructural features of cellular schwannoma and absence of S-100 antigen reactivity. Pathol Res Pract 1989;185:480-485; discussion 486-487.

-5 Matsuda H, Igarashi Y, Ohishi M, et al: A case of omental malignant schwannoma presenting as a huge abdominal tumor (in Japanese). Nippon Shokakibyo Gakkai Zasshi 1984;81:2053-2056.

6 Jhala GS, Goel SP, Arora HL, Goel V: Neurilemmoma of the greater omentum. J Indian Med Assoc 1972;59:391-392.

7 Yilmaz F, Uzunlar AK, Bukte Y, Ozekinci S, Akgun Y: Primary malignant schwannoma of the small bowel. Turk J Med Sci 2001;31:459-461.

8 Sakai F, Sone S, Yanagisawa S, Ishii Z: Schwannoma of the lesser omentum. Eur J Radiol 1988;8:113-114.

-9 Liessi G, Barbazza R, Sartori F, Sabbadin P, Scapinello A: CT and MR imaging of melanocytic schwannomas; report of three cases. Eur J Radiol 1990;11:138-142.

10 Tötterman S, Lindfors O, Nickels J: A schwannoma of the lesser omentum. Rofo 1980;132:585-586.

11 Nowicki S, Domaniewski J: Schwannoma of the major omantal bursa (in Polish). Pol Przegl Chir 1966;38:789-790.

Y. Tanoue and N. Tanaka designed the research. Y. Tanoue and M. Nagai performed the research, analyzed the data and wrote the paper. Y. Suzuki, a clinical pathologist, reviewed the pathological material. 